\title{
PEMAHAMAN HADIS TENTANG OPTIMISME
}

\author{
Siti Hatifah* \& Dzikri Nirwana** \\ *Alumni Jurusan Tafsir Hadis Fakultas Ushuluddin dan Humaniora \\ IAIN Antasari Banjarmasin \\ *Dosen Jurusan Tafsir Hadis Fakultas Ushuluddin dan Humaniora \\ IAIN Antasari Banjarmasin
}

\begin{abstract}
Understanding of hadith (figh al-hadith) is a process of understanding that comes from the hadith of Prophet Mubammad and studies which explores and comprehends the teachings contained in the hadith of the Prophet to be applied. One of the faithful' characteristics is to have an optimistic attitude. Without having an optimistic attitude, someone will destroy bimself. For example, he is easily stress, sad, disappointed, depression, and even suicide. Therefore, an optimistic attitude is very important thing, because optimism is the belief of everything in terms of good and fun, it always has positive thinking and has high expectations.
\end{abstract}

Kata kunci: fiqh al-Hadits, optimisme.

\section{Pendahuluan}

Alquran dan sunnah adalah sumber hukum Islam. Rasulullah saw. telah menjelaskan segala apa yang diturunkan kepadanya berupa Alquran dan sunnah Nabi untuk kebaikan umat manusia dan sebagai pegangan bagi kehidupan dunia dan akhirat. ${ }^{1}$ Islam memerintahkan setiap perkara yang membawa kebaikan bagi setiap muslim pada badan, akal, agama, harta, kesehatan, maupun lainnya. $^{2}$

Kehidupan manusia tidak terlepas dari tekanan.Mengacu pada ajaran Islam, tekanan dapat berupa ujian atau cobaan yang datangnya dari Allah swt., yang harus dihadapi dengan sabar.Islam juga mengajarkan bahwa cobaan sebagai alat untuk perkembangan diri menuju kearah yang lebih baik.

Segala sesuatu itu ada dan akan terjadi sesuai dengan ketentuan qadha' dan qadarnya. Ini merupakan keyakinan orang-orang Islam dan para pengikut setia Rasulullah saw. yakni, keyakinan mereka bahwa segala sesuatu di dunia ini tidak akan pernah ada dan terjadi tanpa sepengetahuan, izin, dan ketentuan Allah swt. ${ }^{3}$

Kemajuan IPTEK dengan segala ragamnya ternyata tidak berhasil mengangkat harkat kehidupan manusia secara hakiki.Yang terjadi justru sebaliknya, banyak terjadi kegelisahankegelisan dan tidak bermaknanya kehidupan serta hampanya nilai spiritual. ${ }^{4}$ Apalagi sekarang meningkatnya angka depresi sehingga orang memutuskan untuk mengakhiri hidupnya.Depresi

${ }^{1}$ Zufran Rahman, Kajian Sunnab Nabi S AW sebagai Sumber Hukum Islam, (Jakarta: CV Pedoman Ilmu Jaya, 1995.), Cet. I, h. 3 .

${ }^{2}$ Abdul 'Aziz bin Fathi, Ensiklopedi Adab Islam menurut Alquran dan Sunnah, terj. Abu Ihsan al-Atsari, (Jakarta: Pustaka Imam asy-Syafi'i, 2007.), Cet. I, h. x.

${ }^{3}$ Aidh al-Qarni, Jangan Bersedih, terj. Samson Rahman, (Jakarta: Qisthi Press, 2008.), Cet. 47, h. 87.

${ }^{4}$ Moh Sholeh, Bertobat sambil Berobat, (Jakarta: Mizan Pustaka, 2008), Cet I, h. 41. 
melanda seluruh dunia, tanpa membedakan letak negara. Penyakit ini menyerang siapa saja, tidak peduli ia kaya dan miskin.

Data Organisasi Kesehatan Dunia (WHO) menyimpulkan bunuh diri telah menjadi masalah besar bagi kesehatan masyarakat di negara maju dan menjadi masalah yang terus meningkat jumlahnya di negara berpenghasilan rendah dan sedang. Hampir satu juta orang meninggal setiap tahunnya akibat bunuh diri. Ini berarti kurang lebih setiap 40 detik jatuh korban bunuh diri. ${ }^{5}$ Kehidupan negara Jepang yang maju ternyata tidak membawa ketenangan bagi masyarakat, terbukti kasus angka bunuh diri pada tahun 2012, 76 orang melakukan bunuh diri dalam perhari. ${ }^{6}$

Sekarang data angka bunuh diri di Indonesia tergolong tinggi, sebanding dengan Jepang. Pada peringkat angka bunuh diri seluruh dunia, Indonesia dan Jepang menempati posisi yang sama di urutan kesembilan. Di Indonesia, angka bunuh diri diperkirakan setiap tahun mencapai 50 ribu orang dari 220 juta total penduduk Indonesia. Walaupun berada pada peringkat yang sama, tapi alasan orang untuk bunuh diri di Indonesia dan Jepang berbeda. ${ }^{7}$

Sedangkan di Indonesia, alasan paling dominan bunuh diri adalah faktor sosial dan ekonomi. Ada juga faktor depresi yang memicu orang lebih baikbunuh diri. Tanda-tanda orang yang berpotensi bunuh diri bisa dikenali. Beberapa di antaranya berbicara tentang bunuh diri, selalu berbicara atau berpikir tentang kematian, membuat komentar yang menjadikan putus asa, tidak berdaya, atau tidak berharga. ${ }^{8}$

Sumber utama kasus bunuh diri ini tidaklah lain adalah depresi, tidak menerima kenyataan hidup, mudah stres, dan tekanan ekonomi. Padahal Allah swt. memberikan segala sesuatu kepada hambanya adalah baik, walaupun menurut kacamata manusia ia membencinya. Karena belum tentu yang dibenci manusia itu buruk baginya dan sebaliknya yang disukai manusia belum tentu baik baginya. ${ }^{9}$ Diiringi dengan keikhlasan menerima kenyataan hidup akan lebih baik dari pada memilih bunuh diri, Allah melarang manusia bersikap putus asa, dalam Q.S. âli-'Imrân/3: 139: "Janganlah kamu bersikap lemah, dan janganlah (pula) kamu bersedih hati. Padahal kamulah orang-orang yang paling tinggi (derajatnya), jika kamu orang-orang yang beriman.”(Q.S âli-'Imrân/3: 139)

Putus asa adalah sikap tercela dan dibenci Allah. Allah swt. memberikan cobaan sesuai dengan kemampuan manusia ${ }^{10}$ dan sabda Rasulullah saw. tentang keadaan seorang mukmin yang menakjubkan dalam menghadapi kesulitan hidup.

Realitas di lingkungan masyarakat, di sekolah, di rumah, bahkan individu masing-masing banyak terpengaruh dengan perkataan yangbernada pesimis, mudah mengeluh, tidak sabar, dan menganggap semua yang terjadi dengan kesialan. Padahal melalui ucapan bernada mengeluh

${ }^{5}$ http://kesehatan.kompasiana.com/kejiwaan/2013/09/10/indonesia-tanpa-bunuh-diri-588351.html, (26-01-2014)

'http://www.tribunnews.com/bisnis/2013/04/07/sungguh-mengerikan-di-jepang-bunuh-diri-pun-jadi-bisnis, (26-01-2014)

${ }^{7}$ Di Jepang ada budaya harakiri, yakni menusuk perut sendiri dengan senjata tajam hingga mati. Ini mereka lakukan sebagai bagian dari kuatnya budaya malu di Jepang. "Misalnya ada pejabat yang ketahuan korupsi, biasanya untuk menutupi perasaan malu, mereka bunuh diri," kata Guru Besar bidang psikiatri Universitas Sebelas Maret Syamsul Hadi, dalam seminar berjudul "Meningkatkan Kepedulian terbadap Gangguan Bipolar di Indonesia" di Hotel Grand Aston, Yogyakarta, Selasa, 25 Maret 2014.

${ }^{8}$ http://www.tempo.co/read/news/2014/03/26/173565394/Angka-Bunuh-Diri-Indonesia-Setara-Jepang, (16-042014)

${ }^{9}$ Lihat Q.S. al-Baqarah/2: 216

${ }^{10}$ Lihat Q.S. al-Baqarah/2: 286 dan al-Thâlaq/65: 7 
adalah awal dari pesimisme. Betapa pentingnya ucapan yang baik sehingga mempengaruhi orang lain untuk selalu berkata baik dan berpikiran positif.

Kata atau perkataan, tidak hanya memiliki suatu arti atau makna, melainkan juga sering membangkitkan kekuatan tertentu atau malah sebaliknya. Kekuatan kata-kata (the power of words) kerap digunakan untuk memotivasi, baik memotivasi diri sendiri maupun orang lain. ${ }^{11}$ Sesuai dengan hadis dibawah ini menggambarkan optimisme dalam bentuk ucapan:

Abd bin Humaid telah menceritakan kepada kami, Abd al-Razzâq telah menceritakan kepada kami, Ma'mar telah menceritakan kepada kami, dari Zuhrî, dari Ubaid Allâh bin Abd Allâh bin Utbah, bahwasanya Abû Hurairah berkata, "Aku telah mendengar Nabi saw. bersabda, "Tidak ada ramalan nasib sial. dan yang terbaiknya adalah optimisme." Ada yang bertanya. "Wahai Rasulullah, apa itu optimisme?" Beliau menjawab, "Yaitu kalimat baik yang didengar oleh salah seorang kalian.” (H.R. Muslim)

Hadis tersebut betapa dahsyatnya perkataan yang penuh harapan dan motivasi dapat membangkitkan kepercayaan diri dan selalu positive thinking. Lain halnya, dengan orang yang pesimis akan mengeluarkan kata-kata yang tidak baik dan selalu mengeluh. Berdasarkan sabda Nabi saw. yang terbaik adalah bersikap optimis. Sikap optimis sangat membantu dalam menghadapi kesulitan atau permasalahan, misalnya orang tidak percaya diri dalam menggapai citacita, mencela dirinya sendiri atau menganggap dirinya sial, menyalahkan orang lain, tidak menerima kegagalan, stres, sedih, kecewa dan depresi. Akhirnya ia mengalami keputusasaan dalam hidupnya. Dari permasalahan itu maka setiap manusia harus percaya diri dan optimis.

\section{Pembahasan}

\section{Pengertian Optimisme}

Optimisme dalam bahasa inggris optimism (harapan baik), optimistic yang artinya berharap baik. ${ }^{12}$ Dalam kamus bahasa Arab, optimisme sering disebut al-tafâul (التفأُ ل). Makna al-tafâulsebagai "Dhid-du al-tasyä̈am" (lawan dari pesimis). Optimis lawan dari pesimis ${ }^{13}$, seperti dalam bahasa Indonesia. ${ }^{14}$ Dalam kamus al-Munawwir, kata al-tafâul diartikan sebagai pengharapan nasib baik. ${ }^{15}$

Dalam terminologi tasawuf ada istilah al-rajâË, maknanya harapan. Istilah ini mirip dengan al-tafâul. Jika optimisme diartikan sebagai "berharapan baik", maka pesimisme bermakna "putus harapan atau putus asa". ${ }^{16}$ Kata lain yang serupa ialah qanitha-qanâthah. (قنط- قناطة) Kata ini bermakna putus asa. ${ }^{17}$

Optimis adalah orang yang selalu berpengharapan atau berpandangan baik dalam menghadapi segala hal. ${ }^{18}$ Optimisme ialah paham atau keyakinan atas segala sesuatu dari segi

\footnotetext{
${ }^{11}$ Sopian Muhammad, Rahasia di Balik Rahasia, (Jakarta: Cakrawala Publishing, 2011.), Cet. I, h. 3.

${ }^{12}$ John M. Echols dan Hassan Shadily, Kamus Inggris Indonesia, (Jakarta: Gramedia, 1995.), Cet. XXI h. 407.

${ }^{13}$ Pesimis adalah putus harapan dan pandangan yang tidak mengandung harapan baik.

${ }^{14}$ AM. Waskito, The Power of Optimism, (Jakarta Timur: Pustaka al-Kautsar, 2013.), Cet. I, h. 1.

${ }^{15}$ Achmad Warson Munawwir, Kamus Arab-Indonesia, (Surabaya: Pustaka Progressif, 1997.), h. 1029.

${ }^{16}$ AM. Waskito, The Power of Optimism, h. 2

${ }^{17}$ Achmad Warson Munawwir, Kamus Arab-Indonesia, h. 1162.

${ }^{18}$ Tim Penyusun Kamus Pusat Bahasa, Kamus Besar Bahasa Indonesia, (Jakarta: Balai Pustaka, 2005.), Cet. 3, h. 801. Eddy Soetrisno, Kamus Populer Bahasa Indonesia, (Jakarta: Ladang Pustaka dan Intimedia, t.th.), h. 108. Saliman dan Sudarsono, Kamus Pendidikan Pengajaran dan Umum, (Jakarta: Rineka Cipta, 1994), Cet. I, h. 165.
} 
yang baik dan menyenangkan, sikap selalu mempunyai harapan baik dalam segala hal. ${ }^{19} \mathrm{Raja} \ddot{\mathrm{E}}$ adalah harapan, kepercayaan atas karunia Allah yang dibuktikan dengan amal. Orang yang berharap adalah orang yang mengerjakan sebab, yakni ketaatan, seraya mengharapkan rida dan pengabulan dari Allah. Orang yang mengharap dan mencari rahmat Allah harus berusaha dengan sungguh-sungguh dan berijtihad dengan penuh ketulusan dan keikhlasan sampai dia memperoleh apa yang dicita-citakannya. Sedangkan khaufialah perasaan takut akibat perbuatannya sehingga termotivasi untuk melakukan kewajiban-kewajbannya. ${ }^{20}$ Pesimis dengan khauf itu berbeda, rajâ̈ dan khauf menjadikan seseorang optimis dalam melakukan segala hal. Khauf disini ada rasa takut atau khawatir yang membuat seseorang berusaha untuk melakukan apa yang dicitacitakannya sehingga berhasil.

Menurut Segerestrom optimisme adalah cara berpikir yang positif dan realistis dalam memandang suatu masalah. Berpikir positif adalah berusaha mencapai hal terbaik dari keadaan terburuk. Lopez dan Snyder berpendapat optimisme adalah suatu harapan yang ada pada individu bahwa segala sesuatu akan berjalan menuju kearah kebaikan. ${ }^{21}$

Jadi, optimisme ialah keyakinan yang ada dalam diri seseorang bahwa segala hal yang terjadi adalah baik, selalu berharap, berpikir positif, dan tindakan yang positif.

\section{Dasar Sikap Optimisme}

Setiap manusia, baik lingkungan keluarga, masyarakat dan negara bahkan secara umum dalam tujuan hidup di dunia tentunya memiliki sebuah pegangan, landasan, dan dasar. Begitu juga, Allah menciptakan semua makhluknya dengan penuh aturan dan penciptaan langit serta bumi ada aturan dan ketentuan-Nya. Apalagi manusia harus teratur dalam mencapai cita-citanya dan teratur dalam menghadapi masalah. Adapun hal yang menjadi dasar dalam bersikap optimis adalah sebagai berikut:

\section{a. Keyakinan dalam Hati}

Keyakinan erat dengan keimanan, adapun orang-orang yang berputus asa adalah mereka yang lemah keimanannya dan lemah jiwanya. Iman yang kuat akan memberikan kekuataan batin bagi seseorang untuk menatap masa depan. Seseorang yang memiliki iman yang kuat memiliki pondasi yang kuat dalam menjalani kehidupan. ${ }^{22}$ Iman bukan sekedar pesan yang diteriakkan, juga bukan sekedar pemanis bibir, melainkan keyakinan yang terpancang kuat dalam lubuk hati, pengetahuan yang memenuhi akal pikiran, serta ajaran yang dianut orang-orang yang beiman. Iman semacam ini merupakan buah kesungguhan, kerja keras, memberi khusyuk, dan akhlak baik. $^{23}$

Individu atau masyarakat yang hidup tanpa agama dan iman bagaikan anai-anai yang ditiup angin, sangat rapuh, lemah, kehilangan tujuan hidup, terasing, mudah terombang-ambing ke sana kemari, selalu diliputi kecemasan yang tidak jelas akhirnya, senantiasa dicekam kebingungan,

\footnotetext{
${ }^{19}$ Tim Penyusun Kamus Pusat Bahasa, Kamus Besar Bahasa Indonesia, h. 801.

${ }^{20}$ Abdul Qadîr 'Isâ, Hakikeat Tasawuf, terj. Khairul Amru, (Jakarta: Qisthi Press, 2005.), h. 202-204.

${ }^{21}$ M. Nur Ghufron dan Rini Risnawita, Teori-Teori Psikologi, (Yogyakarta: Ar-Ruzz Media, 2010.),Cet. I, h. 96.

${ }^{22}$ Mahyuddin Barni, Sumber Sifat Buruk dan Pengendaliannya, (Banjarmasin: Antasari Press, 2007.), h. 156-157.

${ }^{23} \mathrm{Mu}-\mathrm{ammad}$ al-Sayyid Yûsuf dkk, Ensiklopedi Metodologi Alquran, terj. Abu Bakar Ahmad Iman Firdaus, (Jakarta:Kalam Publika, 2007.), h. 66-67.
} 
serta tidak memahami hakikat diri dan rahasia keberadaan wujudnya. ${ }^{24}$ Iman merupakan pendorong, penggerak, pembangun, dan pemercepat alamiah bagi umat Islam untuk bekerja keras dan meraih prestasi yang gemilang. ${ }^{25}$

Keyakinan disini bisa dipahami sebagai niatan dalam hati, yang berarti bila seseorang melakukan sesuatu diiringi dengan niat yang sungguh-sungguh maka akan berhasil. Keyakinan membuktikan bahwa dalam melakukan suatu hal dengan optimis, keyakinan atau niatan merupakan salah satu landasan yang penting demi kesuksesan yang akan dicapai. Keyakinan merupakan landasan dalam berusaha yang muncul dari hati yang dalam dan keyakinan merupakan penyangga keimanan.

\section{b. Berpikiran Positif}

Pikir menurut kamus umum bahasa Indonesia merupakan akal budi, ingatan, angan-angan, kata dalam hati, kira, dan sangka. ${ }^{26}$ Berpikir adalah gejala kejiwaan yang dapat menetapkan hubungan-hubungan antara pengetahuan yang ada. ${ }^{27}$ Berpikir yang diberi tambahan kata positif, dapat diartikan bukan sekedar berpikir yang menggunakan akal, tetapi lebih memerankan perasaan, salah satunya adalah prasangka. ${ }^{28}$

Pikiran akan menjadi suatu kekuatan mental apabila pikiran itu positif, tidak dikotori beragam nafsu dan angan-angan yang negatif. Dr. Maulana Wahiduddin Khan menjelaskan, orang akan benar-benar mampu membentuk kekuatan dalam dirinya bila ia terbebas dari segala ikatan keakuan, itulah saat seseorang mencapai tingkat berpikir dimana semua pertimbangan dangkal telah disingkirkan. Ketika itu pula semua akal pikiran dan sikap tidak dinodai praduga, kemarahan, rakus, kebencian, haus kekuasaan, keangkuhan, mendahulukan kepentingan pribadi, dan berbagai nafsu dasar lainnya. ${ }^{29}$

Zhan berasal dari bahasa Arab yang berarti sangkaan, dugaan, syak, selain istilah ini masih ada kata lain yang bermakna mirip, yaitu syakk yang berarti bimbang dan ragu, dan wahm yang berarti sangkaan ringan, dugaan, dan angan-angan. Zhan berarti sangkaan kuat dalam suatu hal, syakk berarti sangkaannya hampir sama beratnya di antara kiri dan kanan, sedangkan wahm bearti sangkaannya lemah. Jika diprosentasikan maka zhan itu berkisar 75\%, syak berkisar 50\%, dan wahm berkisar $25 \% .^{30}$

Zhan adalah sesuatu yang terbeti di dalam pikiran yang ada kemungkinan benar dan ada kemungkinan salah, namun hal ini dijadikan alasan untuk menghukum dan dijadikan pegangan. ${ }^{31}$ Allah swt. melarang prasangka buruk dalam Q.S. al-Hujurat/49:12.Prasangka dihasilkan dari perbuatan dan perkataan seseorang ${ }^{32}$, maksud prasangka disini adalah tuduhan, dan larangan

\footnotetext{
${ }^{24}$ Muammad al-Sayyid Yûsuf dkk, Ensiklopedi Metodologi Alquran, h. 67-68.

${ }^{25}$ Muammad al-Sayyid Yûsuf dkk, Ensiklopedi Metodologi Alquran, h. 83.

${ }^{26}$ W. J. S. Poerwadarminta, Kamus Umum Bahasa Indonesia, (Jakarta: Balai Pustaka, 2010.), Cet. 7, h. 891.

${ }^{27}$ Akhmad Sagir, Husnuzzhan dalam Perspektif Psikologi, (Yogyakarta: Mitra Pustaka, 2011.),Cet. I, h. 11.

${ }^{28}$ Akhmad Sagir, Husnuzzhan dalam Perspektif Psikologi, h. 24.

${ }^{29}$ Sopian Muhammad, Rahasia di Balik Rahasia, h. 31.

${ }^{30}$ Akhmad Sagir, Husnuzzhan dalam Perspektif Psikologi, h. 53.

${ }^{31}$ Muammad bin Ismail Al-Amir al-Shan'ani, Subulus Salam-Syarah Bulughul Maram, terj. Ali Nur Medan, Darwis, dan Ghana'im, vol. 3, (Jakarta: Darus Sunnah Press, 2008.), Cet. I, h. 896.

${ }^{32}$ Hasan Ayyub, Etika Islam (Menuju Kebidupan yang Hakiki), terj. Tarmana Ahmad Qasim, Sofyan, dan Endang Suhinda, (Bandung: Trigenda Karya, 1994.), cet. I, h. 125.
} 
tersebut pada tuduhan tanpa bukti. Hadis Nabi saw. : iyyâkum wa al-zhan fain al-z̧han akdzab alhaditts ${ }^{33}$ (Jauhilah prasangka karena prasangka adalah perkataan yang paling dusta). Prasangka disebut sebagai perkataan karena prasangka adalah perkataan yang terlintas di dalam hati. Dusta yang dimaksud hadis diatas merupakan sesuatu yang bertentangan dengan kenyataan tanpa ada bukti dan alasan yang benar. Jeleknya perbuatan dusta sudah sangat jelas sehingga tidak perlu dibuktikan lagi. ${ }^{34}$ Agama Islam melarang prasangka buruk (S $\hat{u}$ ' al-z̧han).

Dalam sebuah hadis Qudsi, Allah berfirman, anâ 'inda zhan 'abdî b $\iota^{35}$ (Aku seperti yang diduga atau dibayangkan hamba-Ku). Imam al-Qurthubi, seperti dikutip pakar hadis Ibnu $\underline{\text { Hajar }}$ dalam kitab Fath al-Bârî, menjelaskan dugaan atau sangkaan dimaksud adalah "dugaan pasti dikabulkan jika berdoa, diterima jika bertobat, diampuni jika memohon ampunan (istighfar),

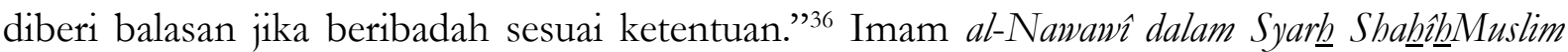
menambahkan, "dugaan akan diberi kecukupan dalam hidup jika ia minta dicukupi." 37

Hadis tadi mengajak untuk bersikap optimis dalam menjalani kehidupan. Sekecil apa pun yang dilakukan, selagi disertai ketulusan, pasti akan diberi balasan oleh Allah swt.. ${ }^{38}$ Sikap optimis inilah yang akan memberi dorongan kuat dalam diri untuk berkarya, berkreasi dan berprestasi.

Dari sikap dasar optimis itu diperlukan realisasi atau perbuatan nyata yaitu dengan adanya harapan, pemikiran yang luas, percaya diri dan sungguh-sungguh. Semua itu akan membawa dampak yang positif dan dapat tercapainya cita-cita yang diimpikan dengan pertolongan Allah.

\section{Ciri-Ciri Optimisme}

Menurut Alan Loy McGinnis, penulis buku The Power of Optimism, orang optimistis berani menerima kenyataan dan mempunyai harapan yang besar pada hari esok. Di antara ciri-ciri utama seorang yang optimistis adalah: a) tidak shock menjalani kesulitan, b) mencari pemecahan permasalahan yang dihadapi, c) merasa mampu (siap) menghadapi masa depan sehingga menumbuhkan semangat dan kekuatan untuk bertahan serta berjuang, d) mengubah pemikiran yang negatif dengan pemikiran yang lebih logis dan positif, e) menerima sesuatu yang tidak bisa diubah seperti cacat fisik atau lainnya. ${ }^{39}$

\section{Konteks Sosio Historis tentang Kata-kata Penuh Harapan}

Konteks sosio historis tentang kata-kata penuh harapan (al-fa') diceritakan oleh Samurah, bahwa Rasulullah saw. merasa takjub dengan kata-kata penuh harapan yang diucapkan Ali pada suatu hari. Ali berkata:'Ini Khadhrah (sebuah tempat di Khaibar)". Bersabda Rasulullah:'Ya, baik kami telah pegang kata-kata penuh pengharapan yang telah diucapkanmu. Maka keluarlah

\footnotetext{
${ }^{33}$ Muslim, Sha- $\hat{\imath}-$ Muslim, vol. 2, h. 517.

${ }^{34} \mathrm{Mu}-a m m a d$ bin Ismail Al-Amir al-Shan'ani, Subulus Salam-Syarah Bulughul Maram, h. 898.

${ }^{35}$ Muslim, Sha- - - Muslim, vol. 2, h. 569.

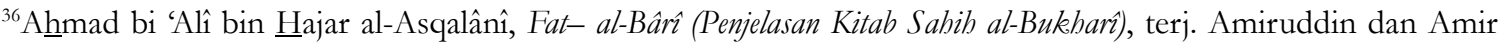
Hamzah, vol. 36, (Jakarta: Pustaka Azzam, 2009.), h. 476.

${ }^{37}$ Abû Zakariyya Yahyâ bin Syaraf al-Nawawî al-Damsyiqî, Syarah Shahîh $\underline{h}$ Muslim, terj. Fathoni Mu-ammad dan Futu-al Arifin,vol. 11, (Jakarta: Darus Sunnah Press, 2011.), Cet. I, h. 939.

${ }^{38}$ Lihat Q.S. âli-'Imrân 195.

${ }^{39}$ Sopian Muhammad, Rabasia di Balik Rahasia, h. 5.
} 
kalian bersama kami." Pergilah mereka ke Khaibar. Tidaklah ada pedang yang dicabut pada waktu itu kecuali pedang Ali. Allah telah membukakan daerah Khaibar bagi mereka. Rasulullah lebih menyenangi kata-kata penuh harapan (optimisme) dari pada kata-kata putus harapan (pesimisme). Diriwayatkan oleh Abû Dâwud dari Abû Hurairah, oleh Ibnu Suni dan Abu Na'im dalam "al-Thibb" dari Katsir bin Abd Allâh bin Amru bin Auf dari ayahnya dari kakeknya, alDailami dari Ibnu Umar, al-Askari dari Sumarah. Al-Suyuthi menilai hadis ini sahih. ${ }^{40}$

Sejarawan menceritakan, ketika sampai di kawasan Khaibar, ucapan Nabi ketika melihat Yahudi membawa peralatan cangkul dan palu, "Allah al-akbar", hancurlah Khaibar. ${ }^{41}$ Kaum muslimin menghadapi perlawanan yang sangat besar ketika hendak meruntuhkan bentengbenteng ${ }^{42}$. Karena Yahudi menyadari sepenuhnya bahwa kekalahan mereka berarti adalah pemusnahan mereka di kawasan jazirah Arab. Dalam kondisi perang yang berkecamuk dan perlawanan mati-matian oleh pihak Yahudi dalam mempertahankan diri serta semangat pengorbanan kaum muslimin, Rasulullah saw. Berkata. "Akan aku berikan panji ini besok kepada seseorang yang Allah akan memberikan kemenangan melaluinya. Orang ini cinta kepada Allah dan Rasul-Nya. Allah dan Rasul-Nya juga cinta kepadanya. Ternyata yang diberikan panji itu adalah Ali bin Abi Thalib. Ali berkata, "Aku akan memerangi mereka sehingga mereka sama seperti kita." Terbukti kemenangan kaum muslimin dalam perang Khaibar. Allah memberikan kemenangan melalui Ali bin Abi Thalib dan menjadikan Yahudi putus asa. ${ }^{43}$

Dilihat konteks Asbâb al-Wurûdal-Haditts tersebut penulis memahami apa yang digambarkan keoptimisan oleh Ali bin Abi Thalib lewat tutur kata, dari sebuah ucapan yang penuh harapan sangatlah luar biasa yang menjadikan kota Khaibar dapat ditaklukkan dan dikuasai oleh umat Islam. Ucapan yang penuh harapan dan motivasi akan menghasilkan pikiran serta perbuatan yang positif, bahkan akan berdampak pada sebuah keberhasilan. Dahulu, umat muslim berperang dalam jumlah pasukan yang lebih kecil dari pada pasukan kafir, akan tetapi kaum muslimin dapat memenangkan perang tersebut dengan izin Allah. Hal itu telah membuktikan pada dunia yang tercatat dalam sejarah Islam dari sebuah perjuangan. Semua itu tidak lain karena pertolongan Allah, keyakinan yang kuat, dan keoptimisan.

\section{Korelasi Optimisme dengan Kesuksesan dan Korelasi Pesimisme dengan Kegagalan}

Kesulitan dan kemudahan adalah dua hal yang senantiasa berputar menimpa diri manusia, silih berganti. Kesulitan identik dengan kegagalan dan kesengsaraan. Seseorang yang ditimpa kesulitan akan berkutat dengan kekhawatiran dan kesedihan. Kemudian yang dimaksud dalam jawaban Umar merupakan bentuk penyikapan terhadap kesulitan, mengubah energi negatif menjadi energi positif. Kemudahan akan mampu mengalahkan kesulitan tatkala dalam diri pemilik kesulitan terpatri sikap optimisme. ${ }^{44}$

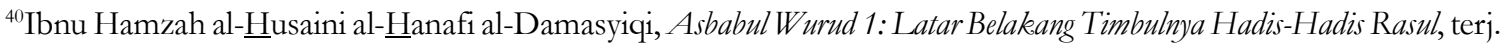
Suwarta Wijaya dan Zafrullah Salim,vol. 1, (Jakarta: Kalam Mulia, 2009.),Cet. 11, h. 62-63.

${ }^{41}$ Ini menunjukkan bolehnya bersikap optimis, karena beliau hanya melihat alat cangkul dan palu yang hanya digunakan untuk bertani, bukan berperang.

${ }^{42}$ Benteng yang dimaksud adalah benteng Na'im dan Qumush, berakhir pada benteng wilayah al-Wathih dan Salalim.

${ }^{43}$ Zaid bin Abdul Karîm al-Zaid, Fikih Sirah: Mendulang Hikmah dari Sejarah Kehidupan Rasulullah saw, terj. Muhammad Rum, Azhari Hatim, dan Abdullah Komaruddin, Cet. I, (Jakarta: Darus Sunnah Press, 2009.), h. 488-489.

${ }^{44}$ Abdul Halim Fathani, Ensiklopedi Hikmah:"Memetik. Buah Kehidupan Dikebun Hikmab”, h. 554.
} 
Sikap optimis akan membawa sinergi kekuatan berpikir seseorang sehingga ia akan melakukan yang dicita-citakan. Sesuai dengan penelitian hadis ini berkata-kata baik akan menumbuhkan harapan, prasangka baik atau berpikir positif dan merealisasikan dengan perbuatan. Sebaliknya bersikap pesimis akan membuat kehilangan gairah dan selalu mengeluh serta perkataan yang tidak baik. Pikiran dan keyakinannya tertanam bahwa ia tidak mampu sehingga menghasilkan kegagalan. Tidak seperti sikap optimisme akan menghasilkan sebuah keberhasilan atau kesuksesan, karena pikiran positif dan keyakinan yang kokoh disertai dengan pertolongan Allah semua menjadi mudah apa yang dihadapi baik masalah itu berat atau ringan, baik tantangan hidup berat atau ringan, dan akan selalu berusaha untuk mewujudkan impiannya. ${ }^{45}$

Putus asa adalah perkara yang dilarang dalam Islam. Banyak faktor yang bisa menyebabkan keputusasaan. Faktor-faktor itu bisa datang dari diri sendiri, dari orang lain, dari lingkungan sekitar, dari kondisi alam, dari situasi perekonomian, dan lain-lain. Kegagalan seringkali menjadi faktor pemicu sikap putus asa. Ketika seorang pelajar tidak lulus sekolah, atau gagal perguruan tinggi negeri. Ada yang putus asa karena gagal dalam seleksi kerja, gagal dalam bisnis, gagal dalam kompetisi, gagal dalam meraih prestasi, gagal meraih kepemimpinan, dan lain-lain. ${ }^{46}$

Hubungan sikap optimis dengan kesuksesan ialah seseorang merasa yakin dengan apa yang dilakukannya untuk mencapai cita-cita. Ketika gagal ia akan mencoba terus dan terus menerus hingga mencapai kesuksesan. Pertanyaannya adalah apakah ada orang yang sukses mengalami keputusasaannya? jelas ada, akan tetapi ia akan bangkit walaupun mengalami kegagalan berulang kali. Jadi, sukses itu identik dengan optimisme seseorang, tetapi orangorang yang sukses pasti ada mengalami keputusasaan dalam hidup. Bedanya orang yang optimis adalah berusaha dan mau bangkit kembali.

Para ulama berkata, "Sesungguhnya Nabi Muhammad saw. menyukai sikap optimis". Karena apabila seseorang mengharapkan nikmat dan karunia Allah swt. ketika ada sebab yang kuat atau lemah dalam sebuah keadaan untuk mendapatkannya, maka dia berada diatas kebaikan pada saat itu meskipun harapannya belum tentu diwujudkan, karena sikap berharap adalah lebih baik baginya. Adapun jika dia memutus harapan dan keinginannya terhadap Allah Taala, maka sesungguhnya itu adalah keburukan baginya. Sedangkan di dalam sikap pesimis terdapat prasangka buruk dan perkiraan akan terjadinya sebuah bencana. ${ }^{47}$ Diantara contoh sikap optimis adalah orang sakit yang optimis dengan apa yang di dengarnya, lalu dia mendengar orang berkata, "Wahai orang yang selamat." Atau orang yang mencari sebuah kebutuhan, lalu dia mendengar orang berkata, "Wahai orang yang telah mendapatkan kebutuhannya." Sehingga di dalam hatinya ada harapan untuk sembuh atau terpenuhi kebutuhannya. ${ }^{48}$

Sikap optimis dan cara pandang positif akan melahirkan bahasa yang positif, baik tutur kata maupun bahasa tubuh. Dalam sebuah hadis Rasulullah bersabda, optimisme (al-fä̈lu) tercermin pada tutur kata yang baik (al-kalimah al-hasanah). Kata-katanya bernadakan optimisme,

\footnotetext{
${ }^{45}$ Pemahaman dari buku-buku yang berkaitan dengan optimisme. Lihat AM. Waskito, The Power of Optimism, Abû Salman Farhan al-Atsary, The Amazing Husnudzon, (Yogyakarta: Qudsi Media, 2013.), Teguh Santoso, Rahasia Mengatasi Putus Asa, Yogyakarta: Tugu, 2011.), Sopian Muhammad, Rahasia Di Balik Rahasia, Mustofa Kamal, Dahsyatnya Optimis, (Surakarta: Ziyad Visi Media, 2012.), Dini Nuris Nuriani, Sang Maha Dekat, (Bandung, Mizan Pustaka, 2011.)

${ }^{46}$ AM. Waskito, The Power of Optimism, h. 12-13.

${ }^{47}$ Al-Nawawî, Syarah Shabih Muslim, vol. 10, h. 541.

${ }^{48}$ Al-Nawawî, Syarah Shabih Muslim, vol. 10, h. 541-542.
} 
seperti, "Masalah itu pasti akan terselesaikan", atau "Dia memang berbakat". Rasul pun, seperti dalam hadis lain, senang mendengar kata "sukses" (yâ najîh) jika akan melakukan sesuatu. ${ }^{49}$

Hadis Nabi Muhammad saw. menjelaskan tafâul dalam bentuk perkataan. Lalu bagaimana dengan tafâul dalam bentuk perbuatan? tafâul dalam bentuk perbuatan dianjurkan dengan dianologikan kepada tafâul dalam bentuk perkataan. Kalau tafâul dalam bentuk perkataan saja dianjurkan dalam Islam, tentunya tafâul dalam bentuk perbuatan lebih patut dan lebih layak disyari'atkan. Karena perkataan yang baik pada tafâul dalam bentuk perkataan merupakan simbol harapan kebaikan, maka demikian juga perbuatan yang baik juga dapat menjadi simbol harapan kebaikan orang melakukan tafâul.

Tafâul tidak hanya dalam bentuk perkataan saja, misalnya, tafâul dalam bentuk memberi dan merubah nama, seperti yang pernah Nabi saw. lakukan kepada seorang bayi yang diberikan nama oleh beliau al-mundzir (pemberi peringatan) sebagai ungkapan optimis agar si anak memiliki ilmu yang digunakannya memberi peringatan. Dan seperti nama ha₹n (sulit) diganti dengan nama sabl (mudah). ${ }^{50}$

Hal ini dikuatkan dengan sikap Nabi saw. yang tidak menyukai sifat pesimis dan senang dengan sifat optimis. Karena jika seseorang bersikap optimis, dia akan giat, merasa bahagia dan akan mendapatkan kebaikan. Namun jika pesimis, dia akan selalu termenung, hatinya sempit dan tidak akan berbuat sesuatu, seandainya dia berbuat ia akan melakukannya dengan terpaksa. ${ }^{51}$ Teks hadis yang diriwayatkan oleh Muslim dari Shuhaib bahwa Nabi Muhammad saw pernah bersabda :

"Haddâb bin Khâlid al-Azdî dan Syaibân bin Farrukh telah menceritakan kepada kami, dari Sulaimân bin al-Mughîrah dan berasal dari lafazSyaibân, Sulaimân telah menceritakan kepada kami, Tsâbit telah menceritakan kepada kami, dari 'Abd al-Rahman bin Abû Laila, dari Shuhaib, Rasulullah saw bersabda, "Sungguh unik perkara orang mukmin itu! Semua perkaranya adalab baik. Jika mendapat kebaikan ia bersyukur, maka itu menjadi sebuah kebaikan baginya. Dan jika ditimpa musibah ia bersabar, maka itu juga menjadi sebuah kebaikan baginya. Dan ini hanya akan terjadi pada orang mukmin.” (H.R. Muslim)

Pemahaman hadis di atas tentang optimisme ialah selalu bersyukur dan bersabar karena menganggap semua kejadian yang dialaminya adalah baik, sesuai dengan pengertian dan pendapat tentang hakikat optimisme. Perkataan dan perbuatan merupakan hubungan yang sangat mempengaruhi manusia menuju kesuksesan.

Optimisme tidak berarti kepercayaan diri berlebih, bukan pula kepasrahan jiwa. Namun berbentuk semangat yang bersemanyam dalam diri untuk senatiasa berusaha dan berupaya ketika kesulitan menimpa. Disamping itu, dalam konteks seorang muslim, optimisme merupakan pemicu agar bersungguh-sungguh dalam melaksanakan suatu pekerjaan, walaupun baru saja menyelesaikan pekerjaan yang lainnya. Tiada kekosongan setelah satu bidang terpenuhi.

${ }^{49}$ Abû al-Thayyib Mu-ammad Syams al-Haqq al-'Adzîm al-Âbâdiy, 'Aun al-Ma'bûd, vol. 10, (Beirut: Dâr al-Fikr, t. th.), h. 413.

${ }^{50}$ Hajar al-Asqalânî, Fat- al-Bârî (Penjelasan Kitab Shabih al-Bukhari), vol. 29, h. 585.

${ }^{51}$ Muammad bin Shali- al-Utsaimin, Syarah Riyadhus Shalibin, terj. Ali Nur, vol. 4, Jakarta Timur: Darus Sunnah Press, 2009.), Cet. II, h. 989. 
Rasulullah saw. Mengajak umatnya agar terus-menerus bekerja dan berusaha tanpa menggantungkan diri kepada oranng lain. ${ }^{52}$ Sabda beliau:

Abd Allâh bin Yûsuf telah menceritakan kepada kami, Mâlik telah menghabarkan kepada kami, dari Abû al-Zinâd, dari al-A'raj, dari Abû Hurayrah, bahwasanya Rasulullah saw. bersabda, "Demi dzat yang diriku ada ditangan-Nya, sunggub seseorang mengambil talinya lalu membawa kayu bakar di atas punggungnya adalah lebib baik dari pada ia datang pada seseorang lalu minta kepadanya, dimana ia diberi atau ditolaknya." (H.R. al-Bukhârî)

Islam mendorong umatnya untuk selalu optimis dan dilarang berputus asa. Bahkan sikap pesimis sangat perlu dihindari, karena di dalamnya terdapat keburukan-keburukan. Di antara keburukan sikap pesimis yaitu:

a. Melemahkan kemauan untuk beramal atau berkarya. Ada kalanya seseorang sudah berniat melakukan suatu kebaikan, tetapi pesimisme membuat berhenti berbuat. Misalnya, seseorang berniat memperbaiki jembatan yang rusak. Hal itu dia lakukan supaya orangorang mendapat kemudahan saat menyeberangi sungai. Tetapi ketika dia akan bekerja, datang orang lain menyakinkan, "sudahlah, jembatan ini tidak perlu diperbaiki. Ia sudah rusak parah, tidak bisa diperbaiki lagi." Kata-kata seperti itu bisa menghentikan niatan berbuat baik. ${ }^{53}$ Jelas hadis Nabi saw. menyukai perkataan baik yang membuat seseorang bersemangat dan melakukan kebaikan, perkataan sangat mempengaruhi seseorang yang mendengar. ${ }^{54}$

b. Menjadi contoh buruk bagi orang lain. Orang yang pesimis bisa mempengaruhi sikap orang lain. Ketika seorang pemimpin pesimis, bawahannya akan ikut pesimis. Seorang guru yang pesimis, murid-muridnya akan ikut pesimis. Seorang tim sepakbola yang pesimis, bisa mempengaruhi anggota timnya. Begitu pula, seorang komandan yang pesimis, akan melemahkan semangat para prajurit di bawahnya. Hingga ada sebuah ungkapan, "jika kita ingin bersemangat, bergaullah dengan orang-orang yang penuh semangat." 55

c. Berburuk sangka kepada Allah. ${ }^{56}$ Orang-orang yang pesimis pada dasarnya telah berburuk sangka kepada Allah.57

d. Membuat kalah dalam persaingan. Ketika terjadi perlombaan atau persaingan, dalam bidang apapun, maka pihak yang paling optimis, berpeluang lebih besar untuk memenangkan perlombaan. Sebaliknya, pihak yang pesimis akan cepat tersingkir. ${ }^{58}$

${ }^{52}$ Abdul Halim Fathani, Ensiklopedi Hikmah:"Memetik Buah Kehidupan Dikebun Hikmah", h. 555.

${ }^{53}$ AM. Waskito, The Power of Optimism, h. 234.

${ }^{54}$ Perkataan penuh harapan dan motivasi sangat mempengaruhi orang lain. Sama halnya yang dilakukan oleh Siti Khadijah, beliau mengatakan kepada Nabi Muhammad saat beliau ketakutan menerima wahyu. Apa yang terjadi, ternyata Siti Khadijah mengatakan dengan penuh optimisme,"Sunguh, berbabagialab engkau. Demi Allah, Allah tidak akan menghinakanmu selamanya. Demi Allah, engkau telah menyambung silaturahmi, engkau berkata secara jujur, memikulkan beban manusia, membantu orang-orang yang terbuang, memuliakan tamu, dan engkau menolong orang-orang yang benar." Sesuai dengan hadis al-fä̈lu dengan perkataan yang menumbuhkan ketenangan jiwa dan ada harapan. Lihat AM. Waskito, The Power of Optimism, h. xiv.

${ }^{55}$ AM. Waskito, The Power of Optimism, h. 235.

${ }^{56}$ Hajar al-Asqalânî, Fat-al-Bâri Penjelasan Kitab Shabih al-Bukhari, vol. 28, h. 357.

${ }^{57}$ AM. Waskito, The Power of Optimism, h. 236.

${ }^{58}$ AM. Waskito, The Power of Optimism, h. 237. 
e. Memicu munculnya penyimpangan perilaku. Orang-orang yang memiliki prilaku menyimpang, dalam agama maupun kehidupan umum, biasanya memiliki latarbelakang kegagalan. Dari kegagalan itu timbul sikap pesimis, lalu berubah menjadi putus asa. Untuk mengatasi kegelisahan hatinya, mereka berprilaku menyimpang. ${ }^{59}$

Sepatutnya sikap optimisme tetap tersemai dihati umat Islam untuk membangun sikap optimisme, setidaknya ada dua hal yang dilakukan:

1. Melakukan perbaikan diri lewat usaha-usaha yang jelas dan amal yang nyata.

2. Yakin akan ada kelapangan di hari kemudian kelapangan dari sebuah kesungguhan, kontinuitas beramal, dan berinovasi tiada henti dengan diiringi keyakinan adanya pertolongan Allah. ${ }^{60}$

Dua hadis Nabi saw. berhubungan dengan sebuah keberhasilan, karena semua perkara yang menimpanya baik susah dan senang, ia akan menganggap semuanya baik. Tidak salah orang-orang sukses percaya diri akan kemampuannya dengan melalui perkataan baik dan perbuatan. Sebuah keberhasilan merupakan hal yang didambakan banyak orang, melihat zaman sekarang banyak orang-orang yang sukses dengan penuh keyakinan, baik orang tersebut beragama Islam ataupun kafir. Semuanya mengamalkan optimisme.

Agama Islam sudak sejak lama mengajarkan kayakinan, berkata, berpikir positif, dan optimis, tidak salah orang-orang yang mengamalkan dalam hidupnya akan mendapatkan sebuah kesuksesan. Sebuah kesuksesan itu bermacam-macam, sukses karier, cinta, kuliah, sembuh dari penyakit, dan lain-lainnya. Yang membedakan orang Islam dan non-Islam adalah syukur dan sabar. Ini merupakan kunci menjalankan kehidupan dengan penuh keikhlasan. Kedua hadis ini sudah menjelaskan dan memberitahukan bahwa untuk mencapai kesuksesan harus lewat perkataan baik, syukur dan sabar. Misalnya, orang yang ingin sukses menjadi pengusaha kuliner, maka orang tersebut akan diuji kesungguhannya agar Allah memberikan kesuksesan yang jauh lebih besar. Apabila ia mampu melewati ujian itu dengan sabar, syukur, dan sikap optimis.

Hadis tersebut dapat dipahami bahwa perkataan yang positif yang bernadakan semangat dapat kita lihat sekarang, ada beberapa acara di televisi orang lain mendengarkan nasehatnasehat kebaikan akan termotivasi untuk melakukan kebaikan, mencapai kesuksesan, dan perbaikan hidup lebih baik lagi. Misalnya, acara Mario teguh "The golden ways", acara tersebut membuktikan perkataan yang baik akan memberikan dampak positif kepada orang banyak saat mendengarkan perkataan tersebut. Dalam bentuk buku, yang diutarakan melalui karya tulisan yang isinya penuh kata-kata ${ }^{61}$ motivasi dan yang membacanya juga akan terpengaruh apa yang ditulis sang pengarang.

${ }^{59}$ AM. Waskito, The Power of Optimism, h. 237-238.

${ }^{60}$ Abdul Halim Fathani, Ensiklopedi Hikmah:"Memetik Buah Kebidupan Dikebun Hikmah", h. 555.

${ }^{61}$ Kata-kata yang positif membawa pengaruh yang sangat luar biasa manfaatnya. Terbuktinya penelitian yang dilakukan oleh Dr. Masaru Emoto melakukan penelitian selama 2 bulan bersama sahabatnya Kazuya Ishibashi (seorang ahli sains yang mahir menggunakan mikroskop) berasal dari Jepang yang meneliti kata-kata yang baik saat diucapkan diair membentuk kristal, sedangkan kata-kata jelek akan terlihat airnya keruh (tidak berbentuk Kristal). Apalagi kata-kata positif diucapkan pada diri sendiri dan didengar orang lain akan memberikan pengaruh positif bagi tubuh. Lihat Masaru Emoto, The True Power of Water: Hikmah Air dalam Olabjiwa, terj.Azam Translator, cet. V, (Bandung: MQ Publishing, 2006), h. 1-23. 


\section{Kesehatan Tubuh Orang yang Memiliki Sikap Optimisme}

Setiap manusia menginginkan kesehatan, baik sehat fisik dan rohani. Memiliki sikap optimis membawa pengaruh bagi kesehatan yakni optimisme dapat membantu meningkatkan kesehatan secara psikologis, memiliki perasaan yang baik, melakukan penyelesaian masalah dengan cara yang logis sehingga hal ini dapat meningkatkan kekebalan tubuh. ${ }^{62}$

Karya Mohammad Ali Toha Assegaf dalam bukunya 365 Tips Sehat ala Rasulullah sejalan dengan penelitian orang Barat yang menyatakan optimisme memiliki pengaruh terhadap kekebalan tubuh. Salah satu kunci sehat adalah selalu berprasangka baik kepada Allah swt.. Prasangka baik kepada Allah swt. akan membuahkan banyak kebaikan. Optimisme agar sembuh dari sakit merupakan bentuk prasangka baik orang mukmin kepada Allah. ${ }^{63}$ Rasa harap akan menumbuhkan optimisme, sedangkan optimisme akan menggairahkan hidup dan menyehatkan badan dengan menyeimbangkan gejolak emosi sehingga semangat hidup terpelihara. ${ }^{64}$ Alquran mengingatkan kepada manusia beberapa kali untuk tidak berputus asa dari rahmat Allah.

Optimisme baik bagi kesehatan dan kesejahteraan dibandingkan dengan pesimisme. Ini bukan berarti bahwa pandangan optimis selalu memperpanjang usia seseorang yang telah terkena penyakit serius, tim yang terdiri dari para peneliti Australia yang mengikuti perkembangan 179 pasien penderita kanker paru-paru selama delapan tahun menemukan bahwa optimisme tidak memiliki pengaruh apapun terhadap siapa yang tetap hidup atau berapa lama mereka hidup. ${ }^{65}$

Namun, dengan memiliki sikap optimis menghasilkan kesehatan yang baik dan bahkan memperpanjang usia orang yang tidak memilki penyakit yang mengancam kehidupan. Sebaliknya, gaya "meramalkan bencana" dari orang yang pesimis memiliki korelasi positif dengan kematian dini. ${ }^{66}$

Orang yang optimis tidak menyangkal bahwa mereka memiliki masalah atau menghindari berita buruk, sebaliknya mereka memandang masalah dan berita buruk sebagai kesulitan yang dapat mereka atasi. Mereka memilki kesehatan yang lebih baik dibandingkan orang yang pesimis. ${ }^{67}$

Karya yang mengubah pemikiran menjadi positif oleh Martin E. P. Seligman, dalam bukunya Menginstal Optimisme ${ }^{68}$, sikap optimisme memiliki kekebalan tubuh lebih bagus dari pada orang yang memiliki sikap putus asa. Penelitian dan observasi yang dilakukan Chis bahwa orang-orang yang pesimis dua kali lebih sering menderita penyakit dari pada orang-orang yang optimis.

Thomases menyatakan bahwa optimisme, depresi, dan putus harapan semuanya mempengaruhi sistem kekebalan tubuh. Sistem kekebalan tubuh terhubung dengan otak dan pernyataan pikiran, seperti harapan yang memiliki hubungan dengan pernyataan pikiran dan mencerminkan psikologi seseorang. ${ }^{69}$

${ }^{62}$ M. Nur Ghufron dan Rini Risnawita, Teori-Teori Psikologi, h. 95.

${ }^{63}$ Mohammad Ali Toha Assegaf, 365 Tips Sehat ala Rasulullah, cet. I, (Jakarta: Mizan Publika, 2009.), h. 28.

${ }^{64}$ Mohammad Ali Toha Assegaf, 365 Tips Sehat ala Rasulullah, h. 31.

${ }^{65}$ Carole Wade dan Carol Tauris, Psikologi Edisi 9, terj. Padang Mursalin dan Dinastuti, (Jakarta: Erlangga, 2007.), h. 297.

${ }^{66}$ Carole Wade dan Carol Tauris, Psikologi Edisi 9, h. 297.

${ }^{67}$ Carole Wade dan Carol Tauris, Psikologi Edisi 9, h. 297.

${ }^{68}$ Martin E. Saligman, Menginstal Optimisme, terj. Budhy Yogapranata, (Bandung: Momentum, 2008.), h. 233.

${ }^{69}$ Martin E. Saligman, Menginstal Optimisme, h. 235. 
Otak dan sistem kekebalan tubuh ${ }^{70}$ terhubung tidak melalui saraf, tetapi melalui hormon, pengirim zat kimiawi yang mengalir melalui darah dan dapat menyampaikan pernyataan emosional dari bagian tubuh yang satu menuju bagian tubuh yang lain. Ketika seseorang mengalami depresi, terjadi perubahan di otaknya. Fakta ini telah didokumentasikan dengan baik. Neurotransmitter, yaitu hormon yang menyebarkan pesan dari satu saraf ke saraf lain sehingga bisa habis. Serangkaian transmitter yang disebut catecholamine habis selama depresi berlangsung. ${ }^{71}$

Dengan rantai penghubung berupa peristiwa fisik apa yang memungkinkan sistem kekebalan tubuh peka atas pesimisme, depresi, atau duka seseorang? Ternyata ketika catecholamine habis, zat kimiawi lain yang disebut endorphin-morfin alami tubuh, meningkatkan aktivitasnya. Sel-sel pada sistem kekebalan tubuh memiliki penerima yang merasakan tingkat endorphin. Ketika catecholamine rendah, seperti yang dialami pada saat depresi, endorphin meningkat, sistem kekebalan tubuh mendekteksi peningkatan ini kemudian melemahkan sistemnya sendiri. ${ }^{72}$

Sekitar sepuluh tahun yang lalu, para peneliti asal Australia yang membentuk sebuah kelompok pelopor mengumpulkan 26 pria yang istrinya baru meninggal dunia karena cedera mematikan atau penyakit. Para peneliti ini membujuk setiap pria untuk menyerahkan sampel darah dua kali, pertama satu minggu setelah kematian istri mereka, dan kedua, lima minggu setelahnya. Dengan sampel darah yang diberikan, para peneliti bisa mengamati sistem kekebalan tubuh selama berduka. Mereka menemukan bahwa sistem kekebalan tubuh melemah selama berduka. Seiring berjalannya waktu, sistem kekebalan tubuh mulai pulih. ${ }^{73}$

Semua bukti ini membuat jelas keadaan psikologi yang dapat mengubah tanggapan sistem kekebalan tubuh. Kehilangan harapan, depresi, dan pesimisme dapat menurunkan aktivitas sistem kekebalan tubuh. ${ }^{74}$ Perasaan cemas, tertekan atau depresi, dan merasa tidak berdaya, dapat memperlambat penyembuhan luka setelah operasi, sedangkan perasaan optimis dan penuh harap dapat sangat mempercepat penyembuhan. Perasaan kesepian dan kecemasan dapat menurunkan sistem kekebalan tubuh dan memungkinkan virus yang tidur (dormant) dalam tubuh, seperti herpes. ${ }^{75}$

Berdasarkan hadis Nabi Muhammad saw. bahwa beliau menyukai optimisme, kuat seorang mukmin, dan positive thinking adalah karakter mukmin yang tangguh. Rasulullah saw. sudah memerintahkan kepada umat muslim untuk selalu optimisme dalam menjalankan kehidupan di dunia ini dan selalu husnuzhan. Karena akan berdampak kepada kesehatan rohani dan jasmani, diatas sudah dibahas panjang lebar bahwa seseorang yang memiliki sikap optimis dan positive thinking akan mempengaruhi kekebalan tubuh.

${ }^{70}$ Kekebalan tubuh (imunitas) terdiri dari sel-sel yang melindungi tubuh dari substansi penggangu, seperti virus dan bakteri. Apabila stres yang terjadi dalam waktu yang lama akan memicu sekresi hormon korsitol dari kelenjar adrenal. Hormon tersebut akan meningkatkan kadar gula darah serta meningkatkan metabolisme. Perubahan tersebut membantu tubuh untuk tetap melakukan suatu aktivitas dalam waktu yang lama, dengan imbalan berupa penurunan aktivitas sistem imunitas. Lihat James W. Kalat, Biopsikologi (biological psychology), terj Dhamar Pramudito, (Jakarta: Salemba Humanika, 2010), h. 162-163.

${ }^{71}$ Martin E. Saligman, Menginstal Optimisme, h. 235-236.

${ }^{72}$ Martin E. Saligman, Menginstal Optimisme, h. 236.

${ }^{73}$ Martin E. Saligman, Menginstal Optimisme, h. 236.

${ }^{74}$ Martin E. Saligman, Menginstal Optimisme, h. 236-237.

${ }^{75}$ Carole Wade dan Carol Tauris, Psikologi Edisi 9, h. 292. 
Betapa agungnya ilmu dan pengajaran yang dibawa oleh Islam, dan betapa indahnya ayatayat Alquran, sebagaimana indahnya sabda Nabi Muhammad saw. Bahwa beliau selalu menunjukkan sikap optimis dan memberikan berita gembira berupa rahmat dari Allah, dan beliau tidak pernah merasa sedih atas berbagai urusan dunia, karena beliau selalu mengamalkan firman-firman Allah.

Para peneliti barat sudah menyimpulkan bahwa orang yang memiliki sikap pesimis akan menurunkan kekebalan tubuh dan sikap optimis akan memberikan pengaruh positif terhadap kesehatan tubuh. Allah swt. telah memerintahkan kepada kita untuk optimis, kuat jiwa dan mental. Nabi Muhammad saw. juga menyuruh kepada kita untuk selalu optimisme. Ayat Alquran dan hadis merupakan perintah yang harus dilaksanakan hambanya. Semua itu untuk kebaikan umat manusia, terutama muslim.

\section{Penutup}

Landasan dan bentuk optimisme ini menggambarkan karekter orang-orang beriman, menjadi bukti keimanan umat muslim, melalui keteguhan, keyakinan, positive thinking, syukur dan sabar. Tidak hanya itu, ucapan yang positif akan mempengaruhi pemikiran seseorang yang mendengarnya. Oleh karena itu, Nabi saw. menyukai sikap optimis ini dan beliau selalu optimis serta tidak pernah merasa sedih atas segala urusan dunia.

Dilihat dari konteks historis hadis tentang bentuk optimisme ialah perkataan Ali bin Abi Thalib yang penuh harapan dan keoptimisan dalam perang Khaibar. Optimisme tidak hanya dipahami dalam peperangan saja, melainkan bisa optimisme dalam segala hal. Hadis-hadis tentang landasan dan bentuk optimisme ini membawa kesuksesan dalam menjalankan kehidupan, kesuksesan itu berbagai macam, sukses karier, cinta, kuliah, dan lainnya. Orang yang memiliki sikap optimis akan membawa dirinya kepada kesehatan jasmani dan rohani.

Optimisme dalam bentuk ucapan ini sangat penting, karena akan menimbulkan berpikir positif dan perbuatan positif. Optimis dalam bentuk ucapan merupakan simbol dari optimis dalam bentuk perbuatan, optimis dalam ucapan saja sangat dianjurkan apalagi dalam bentuk perbuatan. Allah melarang kita untuk berputus asa, karena sikap pesimis adalah akhlak tercela. Kata-kata penuh harapan tidak hanya mempengaruhi pemikiran orang lain melainkan diri sendiri. Ucapan yang buruk akan berdampak pada kesehatan tubuh, sebaliknya dengan ucapan baik diiringi dengan positive thinking serta perbuatan yang positif akan luar biasa manfaatnya yakni mendapatkan kekebalan tubuh, hati menjadi tenang dan ikhlas dalam menerima kenyataan hidup. Ucapan yang baik yang membangkitkan gairah hidup yang dikenal dengan kata-kata motivasi ini sejalan dengan para motivator yang selalu mengucapkan kalimat hasanah atau al-fä̈lu dalam acara televisi, seminar-seminar, dan dalam bentuk karya tulisan.

\section{DAFTAR PUSTAKA}

\section{Al-Qur'ân al-Karîm}

Âbâdiy, Abû al-Thayyib Mu-ammad Syams al-Haqq al-'Adzîm, (t. th).'Aun al-Ma'bûd. vol. 10. Beirut: Dâr al-Fikr.

Abdullah, Adil Fathi (2004).Membangun Positive Thinking secara Islam terj. Faishal Hakim Halimy. Cet. I. Jakarta: Gema Insani Press. 
Al-Amir al-Shan'ani, Mu-ammad bin Ismâ'îl.(2008).Subulus Salam-Syarah Bulughul Maramterj.

Ali Nur Medan, Darwis, dan Ghana'im. Vol. 3. Cet. I. Jakarta: Darus Sunnah Press. Assegaf, Mohammad Ali Toha,(2009). 365 Tips Sehat ala Rasulullah.Cet. I. Jakarta: Mizan Publika. Atsary, Abu Salman Farhan. (2013).The Amazing Husnudzon. Cet. 3. Yogyakarta: Qudsi Media. Ayyûb, Hasan,(1994). Etika Islam (Menuju Kehidupan yang Hakiki terj. Tarmana Ahmad Qasim, Sofyan, dan Endang Suhinda. Cet. 1. Bandung: Trigenda Karya.

Al-Bukhârî, Abû 'Abd Allâh Mu-ammad ibn Ismâ'îl ibn Ibrâhîm Ibn Mughîrah ibn Barzibah al-Ju'fi.(1994).Sha-î- al-Bukhârî. Vol. 4.Beirut: Dâr al-Fikr.

Emoto, Masaru, (2006). The True Power of Water: Hikmah Air dalam Olabjiwa, terj.Azam Translator. Cet. V. Bandung: MQ Publishing.

Fathani, (2008).Abdul Halim.Ensiklopedi Hikmab:"Memetik Buah Kehidupan Dikebun Hikmah". Cet. I,. Yogyakarta: Darul Hikmah.

Fathi, Abdul 'Aziz bin,(2007).Ensiklopedi Adab Islam Menurut Alquran dan al-Sunnabterj. Abu Ihsan al-Atsari. Cet. I.Jakarta: Pustaka Imam Asy-Syafi'i.

Ghufron, M. Nur dan Rini Risnawita,(2010). Teori-Teori Psikologi. Cet. I. Yogyakarta: Ar-Ruzz Media.

Ibnu Hajar al-'Asqalânî, Ahmad bi 'Alî bin, (2008). Fat- al-Bârî (Penjelasan Kitab Shabih alBukhari)terj. Amiruddin dan Amir Hamzah. Vol. 28. Cet. I. Jakarta: Pustaka Azzam. Ibnu Hamzah, (2009). al-Husaini al-Hanafi Damasyiqi. Asbabul Wurud 1: Latar Belakang Timbulnya Hadis-hadis Rasul, terj. Suwarta Wijaya dan Zafrullah Salim,Vol. I. Cet. 11. Jakarta: Kalam Mulia.

'Isâ, (2005).'Abdul Qadîr . Hakikat Tasawnf,terj. Khairul Amru. Jakarta: Qisthi Press.

M. Echols, John dan Hassan Shadily,(1995). Kamus Inggris Indonesia. Cet. XXI. Jakarta: Gramedia. Mahyuddin, Barni,(2007).Sumber Sifat Buruk dan Pengendaliannya. Banjarmasin: Antasari Press. Muhammad, Sopian.(2011). Rahasia di Balik Rabasia. Cet. I. Jakarta: Cakrawala Publishing. Munawwir, Achmad Warson.(1997). Kamus Arab-Indonesia. Surabaya: Pustaka Progressif.

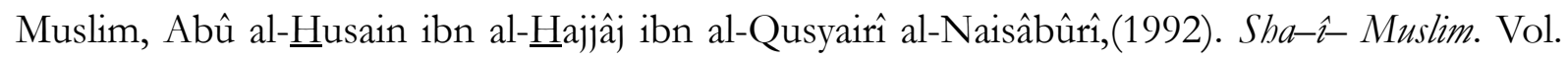
8. Beirut: Dâr al-Fikr.

Al-Nawawî, Abû Zakariyya Yahyâ bin Syaraf.(2011).Syarah Shabih Muslim terj. Fathoni Muhammad dan Futuhal Arifin.. Vol. 11. Cet. I . Jakarta: Darus Sunnah Press.

Nuriani, Dini Nuris.(2011). Sang Maha Dekat. Bandung: Mizan Pustaka.

Poerwadarminta, W. J. S.(2010).Kamus Umum Bahasa Indonesia. Cet. 7. Jakarta: Balai Pustaka. Pradiansyah, Arvan,(2009). The 7 Laws of Happiness: Tujub Rahasia Hidup Yang Bahagia, Cet. IV. Bandung: Kaifa.

Al-Qarni, Aidh,(2008).Jangan Bersedih terj. Samson Rahman. Cet. 47. Jakarta: Qisthi Press. Rahman, Zufran,(1995). Kajian Sunnab Nabi SAW sebagai Sumber Hukum Islam, Cet. I. Jakarta: CV Pedoman Ilmu Jaya.

Sagir, Akhmad, (2011). Husnuгzhan dalam Perspektif Psikologi. Cet. I, Yogyakarta: Mitra Pustaka. Saligman, Martin E, (2008). Menginstal Optimisme terj. Budhy Yogapranata. Bandung: Momentum. Saliman dan Sudarsono,(1994).Kamus Pendidikan Pengajaran dan Umum.Cet. I. Jakarta: Rineka Cipta.

Sholeh, Moh. (2008). Bertobat sambil Berobat.Cet. I. Jakarta: Mizan Pustaka. 
Tim Penyusun Kamus Pusat Bahasa.(2005).Kamus Besar Bahasa Indonesia. Cet.3. Jakarta: Balai Pustaka.

Al-Utsaimin, Mu-ammad bin Shali-,(2009). Syarah Riyadhus Shalibinterj. Ali Nur. Vol. I.Cet. 2.Jakarta Timur: Darus Sunnah Press.

Wade, Carole dan Carol Tauris,(2007).Psikologi Edisi 9 terj. Padang Mursalin dan Dinastuti. Jakarta: Erlangga.

Waskito, AM.(2013).The Power of Optimism. Cet. I. Jakarta Timur: Pustaka Al-Kautsar.

W. Kalat, James, (2010).Biopsikologi (biological psychology) terj Dhamar Pramudito. Jakarta: Salemba Humanika.

Yunus, Mahmud.(2010). Kamus Arab Indonesia. Jakarta: Mahmud Yunus Wa Dzurriyyah.

Yusuf, Ahmad M.(2009). Ensiklopedi Tematis Ayat Alquran dan Hadis.Vol. 5. Jakarta: Widya Cahaya.

Yûsuf, (2007). Mu-ammad al-Sayyid dkk.Ensiklopedi Metodologi Alquran terj. Abu Bakar Ahmad Iman Firdaus. Jakarta:Kalam Publika.

Zaid, Zaid bin Abdul Karîm, (2009).Fikih Sirah: Mendulang Hikmah dari Sejarah Kebidupan Rasulullah saw terj. Muhammad Rum, Azhari Hatim, dan Abdullah Komaruddin. Cet. I. Jakarta: Darus Sunnah Press 